\title{
特集一次世代超硬質材料の超高圧合成とナノ 組織制御一
}

\section{微粒ダイヤモンド多結晶体による超精密加工}

Precision Machining of Al Alloy with a Fine-grained Polycrystalline Diamond Tool

\section{大橋 忠一}

\section{Tadakazu OHASHI}

\begin{abstract}
A fine-grained diamond compact synthesized using a mixed sintering agent of magnesium carbonate and oxalic acid dihydrate was evaluated through precision machining of aluminum alloys in comparison with natural single crystals of diamond. The flank wear of the tool made of polycrystalline compact was half that of single crystal. And the tool made of polycrystalline compact achieved as excellent a surface finish as that of single crystal.

[precision machining, diamond, Al alloy]
\end{abstract}

1. はじめに

近年の情報機器関連の発展はめざましく，高速化・ 高機能化はもちろんのこと小型化・高密度化はとどま ることを知らず，機器に組み込まれている電子および 光学精密部品の精度に対する要求はますます厳しくな つている。これら精密部品は製品の性能を大きく左右 するため，ほとんどが超精密加工により高精度に製造 されている。例えば，ビデオレコーダ用のドラムおよ びガイド等電子精密部品, レーザプリンタに使用され るポリゴンミラーや非球面レンズ，フレネルレンズ等 光学精密部品がある。また, これらの光学部品を成形 するための精密金型の製造にも超精密加工が使用され ている。携帯電話等に搭載されている小型カメラのレ ンズは精密金型による成形で製造している。

超精密加工には切削加工, 研削加工等があるが, こ こでは, 切削加工について述べる。超精密切削加工へ の取り組みは古く 1940 年頃にはオランダ Philips 社が ダイヤモンド工具を使用してテレビの光学系精密部品 を作製している[1]。1960 年には LLL(米国 Lawrence Livermore National Laboratory)の J.B. Bryan は micro inch machining というタイトルで銅やアルミニウムの鏡面 切削が可能であることを発表している[2][3]。超精密切 削加工が可能となったことで，磨きによる仕上げが不 可欠であった上記のような超精密加工品が容易にかつ
安価に得られるようになった。超精密切削加工はメー カーにとって重要な技術としてとらえられており，加 エノウハウ流出防止のためにコスト高の国内工場で行 っている場合もある。超精密切削加工は情報機器産業 の発展を支えるキーテクノロジーの 1 つと考えられる。 超精密加工には, 非常に優れた耐摩耗性と鋭利な刀 先エッジが要求されるため単結晶ダイヤモンド工具が 主に用いられている[2]。また，ダイヤモンド単結晶に は合成品と天然品が用いられているが，仕上げ面粗度 が要求される分野には経験から天然ダイヤモンドが主 に用いられている。単結晶ダイヤモンドは超精密加工 に適した性能を有しているが, 単結晶であるため䢃開 性を示し，欠け易いという問題をもっている。また， 天然ダイヤモンドの場合は不純物および欠陥が一定で はなく, 特性が安定しない。その結果, 工具寿命がば らつくという問題もある。J.M. Oomen らはダイヤモン ドの種類により耐摩耗性が異なるという知見を得てい る[4]。

ダイヤモンド工具には単結晶の他にダイヤモンド粒 子を超高圧・高温下で焼結した多結晶体がある。ダイ ヤモンド多結晶体は樣々な結晶面を有するダイヤモン ド粒子間に部分的に直接結合をもっている焼結体であ るため,特定の䢃開面をもたず耐チッピング性に優れ， 安定した特性を有している。現在 , ダイヤモンド多結 晶体工具は自動車部品, 航空機部品の加工等に幅広く

† 311-0102 茨城県那珂郡那珂町向山 1002-14 三菱マテリアル(株)総合研究所那珂研究センター先進プロジェクト推進部, 科学 技術振興事業団 Central Research Institute Naka Research Center, R\&D Projects Department, 1002-14 Mukohyama, Naka-machi, Naka-gun, Ibaraki-ken, 311-0102. ohashi@mmc.co.jp, Core Research for Evolutional Science and Technology, Japan Science and Technology Corporation, c/o NIRIM 
使用されている。しかし，超精密加工には多結晶体工 具はほとんど使用されない。多結晶体はダイヤモンド 粒子間に部分的に直接結合をもっている焼結体であり， 刃先エッジの形状はダイヤモンド粒子の大きさに依存 する。サブミクロンより高い形状精度が要求される超 精密加工では多結晶体中の粒子の大きさが問題となつ てくる。従来の多結晶体は数ミクロン以上の粒子径で あるので超精密加工に必要な鋭利な刀先が得られず， 希望の形状精度が得られないことが兴の理由と考えら れる。

もし，非常に微細な組織を有する微粒ダイヤモンド 多結晶体が作製できれば鋭利な刃先エッジを有し，特 性の安定した超精密加工用工具の作製が可能となる。 多結晶体は午の製法から量産効果によるコストダウン も見込める。微粒ダイヤモンド多結晶体は理想的な超 精密加工用工具素材になると考えられる。

これまで，いくつかの微粒ダイヤモンド多結晶体が 提案されているが, 助剂量が多いため十分な耐摩耗性 が得られておらず[5][6]，耐摩耗性と鋭利な刀先エッジ 両方を有する微粒ダイヤモンド多結晶体は合成されて いない。最近，赤石によって新しい助剂を用いた微粒 ダイヤモンド多結晶体が開発された[7]。この多結晶体 の切削性能を評価したところ従来ダイヤモンド多結晶 体より優れた耐摩耗性を示し [8]，超精密加工において も単結晶ダイヤモンドと同等の性能を示すことがわか った[9][10][11]。以下, 超精密加工における微粒ダイヤ モンド多結晶体の特性について報告する。

\section{2. 微粒ダイヤ多結晶体による超精密加工}

\section{1 実験方法}

超精密加工の評価に用いた微粒ダイヤモンド多結晶 体は赤石により開発された非金属助剂ダイヤモンド多 結晶体である。原料粉末には $0 \sim 1 \mu \mathrm{m}$ 天然ダイヤモン ド粉末を用いており, 助剂には炭酸マグネシウム +0.1 $\mathrm{mol}$ シュウ酸二水和物を用いている。処理条件は, 圧 力 $7.7 \mathrm{GPa}$, 温度 $2300^{\circ} \mathrm{C}$ ，保持時間 20 分である。

微粒ダイヤモンド多結晶体の評価は 2 種類のアルミ 合金を超精密加工することで行った。ひとつは電子精 密部品であるビデオレコーダのドラム等に使用されて いる日本軽金属製 $\mathrm{ADC} 12$ に対する切削性能を評価し た。ADC12 はダイカスト用アルミ合金で Table 1 に示 すようにアルミの他にシリコンおよび銅が添加されて いる。ドラムはテープが走行するため耐摩耗性も要求 される。ADC12 は，多量の $\mathrm{Si}$ て鋳造性を改善し， Cu を固溶させて強さを高めている(Table 2)[12]。工具への
耐摩耗性が求められる材料であるので, 評価において は仕上げ面粗度と工具刃先の摩耗量を評価した。

もう一つは, 光学精密部品であるレーザープリンタ のポリゴンミラー等に使用される日本軽金属製 S3M に対する切削性能を調べた。S3M は超高純度アルミニ ウム地金に $\mathrm{Mg}$ を主とした 2〜3の元素を添加した合金 である。光学用であるので光の反射率が重要で $\mathrm{ADC} 12$ と異なり金属間化合物の析出がほとんどないとされて いる[12]。S3M は表面性状を利用する用途が多いので， 評価は仕上げ面粗度を中心に行った。

切削条件を Table 3 に示す。切削油には灯油を使用し た。ADC12 送り，切り込みともに $35 \mu \mathrm{m} ， \mathrm{~S} 3 \mathrm{M}$ ではさ らに小さく送り，切り込みともに $5 \mu \mathrm{m}$ でおこなった。 本研究で被削材回転数を一定にして加工しているのは， 回転数か変化する場合に生じる回転軸のわずかな振れ による加工精度の低下を防ぐためである。比較材には， 天然ダイヤモンド単結晶を使用した。比較に使用した 天然ダイヤモンド単結晶は, 2 種類である。外観色か ら「無色」、「茶色」としている。経験的ではあるが， 刃付け性等から「無色」の方が「茶色」のものよりグ レードが高いとされている。使用工具は ,Fig. 1 に示す ような特殊ロウ付けバイトで刃先 R $0.8 \mathrm{~mm}$ ，すくい角 0 ，逃げ角 5 。，超硬合金製シャンクである。単結晶 工具は, すくい面が(110)面，逃げ面が(100)面になるよ うに作製した。加工機は，理研製鋼製超精密 $\mathrm{CNC}$ 旋盤 UPL-1 K である。刀先および被削材観察には光学顕微 鏡および走査型電子顕微鏡(SEM)を使用した。仕上げ 面粗度の測定にはテーラー・ホブソン製フォームタリ サーフを使用した。

Table 1. Composition of aluminum alloy (wt $\%$ ).

\begin{tabular}{|c|c|c|c|c|c|}
\hline Name & $\mathrm{Si}$ & $\mathrm{Cu}$ & $\mathrm{Mg}$ & $\mathrm{Fe}$ & $\mathrm{Al}$ \\
\hline \hline ADC12 & 10.8 & 2.5 & - & - & Bal. \\
\hline $\mathrm{S} 3 \mathrm{M}$ & 0.005 & 0.001 & $3.7-4.7$ & 0.004 & Bal. \\
\hline
\end{tabular}

Table 2. Mechanical properties of aluminum alloy.

\begin{tabular}{|c|c|c|c|}
\hline Name & $\begin{array}{c}\text { Tensile } \\
\text { strength } \\
\left(\mathrm{N} / \mathrm{mm}^{2}\right)\end{array}$ & $\begin{array}{c}0.2 \% \text { yield } \\
\text { strength } \\
\left(\mathrm{N} / \mathrm{mm}^{2}\right)\end{array}$ & $\begin{array}{c}\text { Brinell } \\
\text { hardness HB }\end{array}$ \\
\hline \hline ADC12 & 228 & 154 & 74.1 \\
\hline S3M & 216 & 88 & 58 \\
\hline
\end{tabular}


Table 3. Cutting conditions.

\begin{tabular}{|l|c|c|c|}
\hline Name & $\begin{array}{c}\text { Cutting } \\
\text { velocity } \\
(\mathrm{m} / \mathrm{min})\end{array}$ & $\begin{array}{c}\text { Depth of cut } \\
(\mathrm{mm})\end{array}$ & $\begin{array}{c}\text { Feed rate } \\
(\mathrm{mm} / \mathrm{rev})\end{array}$ \\
\hline \hline ADC12 & $113-280$ & 0.035 & 0.035 \\
\hline S3M & $47-153$ & 0.005 & 0.005 \\
\hline
\end{tabular}

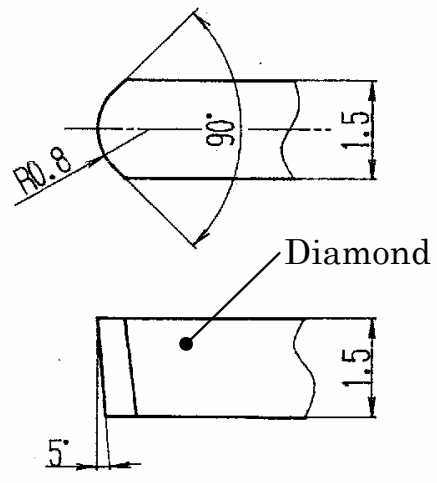

Fig. 1. Enlarged view of tool edge.

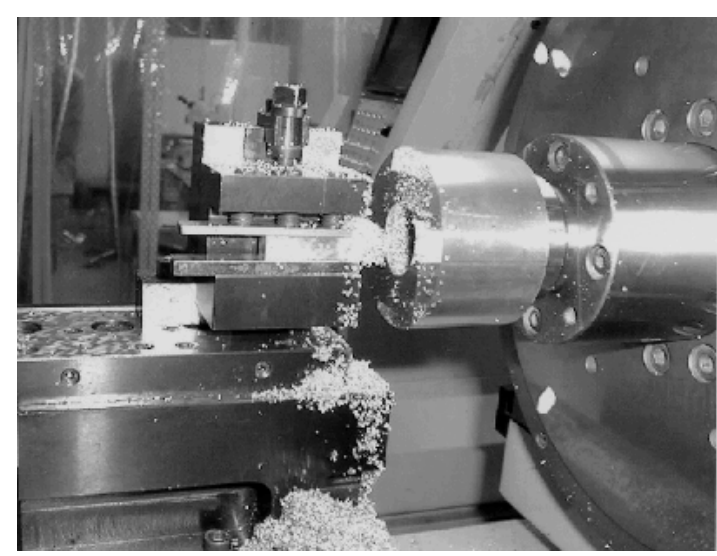

Fig. 2. Overview of cutting test.

\section{$2.2 \mathrm{ADC} 12$ の超精密加工}

加工の樣子を Fig. 2 に示す。図右側の円筒形状のも のが被削材であり，左側が固定された工具である。刀 先は切り屑に隠れてよく見えない。排出される切り屑 はカールしており，適当な長さで自然に分断されるた め，通常のアルミ合金切削加工と違いブレーカー等を 用いて切り屑を分断する必要はない。

$\mathrm{ADC12} 80 \mathrm{~km}$ 加工した後の逃げ面摩耗幅を測定し
た。微粒ダイヤモンド多結晶体は天然ダイヤモンド単 結晶の約半分しか摩耗せず，優れた耐摩耗性を示すこ とが確認された。加工後の工具刃先を光学顕微鏡によ り観察した。単結晶の場合，種類によらず摩耗部と末 摩耗部の境界部分がはっきりとしているのに対して微 粒ダイヤモンド多結晶体は摩耗部と未摩耗部の境界が 比較的曖昧であつた。境界部分の違いは, 単結晶の摩 耗がダイヤモンド自身の摩滅により進行しているのに 対して多結晶体の摩耗がダイヤモンド粒子の摩滅と粒 子の脱落両方で進行していることによると考えられる。

また, 単結晶の摩耗部はすくい面から観察すると横 に長い三角形に近い形状をしており，多結晶体と明ら かに異なっていた。単結晶で三角形状に摩耗が進行す るのは摩耗し易い結晶面から摩耗が進行している可能 性を示唆している。方位依存性がない多結晶体で, 光 のような形状が観察されないことからもこの可能性が 高い。更に刀先摩耗部をよく観察するために，SEM で $80 \mathrm{~km}$ 加工後の刀先エッジの観察をおこなった。単結 晶の場合，加工後の刀先は面取りされたように斜めに 摩耗していた。これに対して多結晶体は加工前の刀先 エッジ形状を保っていた。しかし, ダイヤ粒子の摩滅 および脱落により刀先には細かな凹凸ができていた。 多結晶体のダイヤモンドの摩耗体積は単結晶よりかな り小さかった。SEM 観察からも多結晶体は単結晶に比 へ耐摩耗性が優れていることがわかった。

次に仕上げ面粗度を加工長 $40 \mathrm{~km}$ と $80 \mathrm{~km}$ で測定し た。 $80 \mathrm{~km}$ 加工後の多結晶体の平均面粗度 Ra は $0.06 \mu \mathrm{m}$ 程度で, 単結晶と同等であった。 $40 \mathrm{~km}$ と $80 \mathrm{~km}$ での 面粗度の変化は単結晶より多結晶体が小さく安定して いた。

加工面を光学顕微鏡により観察した結果, 単結晶の 場合は, 刀先摩耗形状の転写により，送り量に対応す る大きなうねりが観察された。多結晶体の場合は，刃 先の後退量が小さいことを反映して大きなうねりは観 察されず，ダイヤモンド粒子径に対応すると考えられ る細かなすじ状の模樣が観察された。また, 単結晶の 場合には析出 Si と考えられる凹凸も観察されたが, 多 結晶体の場合には析出 Si と考えられる部分がはっきり と観察されず，ぼんやりとしたくぼみとして観察され た。

刀先を観察した結果, 単結晶は多結晶に比べて刀先 の摩耗は早いが常に鋭利なエッジを形成するように摩 耗が進行していた。多結晶体は摩耗進行が遅く加工前 の刃先エッジを保っているが刃先自体の鋭利さは失わ れていた。単結晶では析出 Si を切断しているのに対し て，多結晶体では切断できず，押しつけ，もしくは脱 
落させている可能性があり，これが表面状態の差にな って現れたと考えられる。

以上より,ADC12 の超精密加工において微粒ダイヤ モンド多結晶体は天然ダイヤモンド単結晶より優れた 耐摩耗性と同等の仕上げ面粗度を得られることがわか った。

\subsection{S3M の超精密加工}

$5 \mu \mathrm{m}$ と非常に小さい切り込み量であるが, 系状の連 続した切り屑が排出された(Fig. 3)。500 km 加工後に刀 先の観察をおこなった(Fig. 4)。単結晶のすくい面には， 多結晶体には無いクレータ状の摩耗が観察された。こ れは，切り屑がすくい面を擦ることにより形成された と考えられる。刀先の鋭利さに関しては, 単結晶が摩 耗により刀先が後退しているものの鋭利さは失ってい ないのに対して，多結晶体はやや丸みを帯びたエッジ になっていた。

次に仕上げ平均面粗度 Ra を評価した。加工初期で は，単結晶は多結晶体に比較して優れた面粗度を示し た。しかし, 加工が進むにつれて単結晶の Ra は低下し 加工長 $300 \mathrm{~km}$ 以降は, 単結晶と多結晶体の平均面粗度 の差は $0.005 \mu \mathrm{m}$ 以下と非常に小さくなった。 Ra は約 $0.03 \mu \mathrm{m}$ であった。加工長 $500 \mathrm{~km}$ での仕上げ面粗度の 測定結果を Fig.5 に示す。多結晶体は単結晶と同等の仕 上げ面粗度が得られることがわかった。

微粒ダイヤモンド多結晶体は，初期から平均面粗度 $\mathrm{Ra}=0.025 \mu \mathrm{m}$ 以上であったが, 加工長 $500 \mathrm{~km}$ までの 範囲では加工長に依存せず平均面粗度 $\mathrm{Ra}=0.03 \mu \mathrm{m}$ 前 後で推移しており安定していた。この傾向は, $\mathrm{ADC} 12$ の場合と同樣であった。加工面粗度の安定性という観 点では, 多結晶体は単結晶より優れていることがわか った。

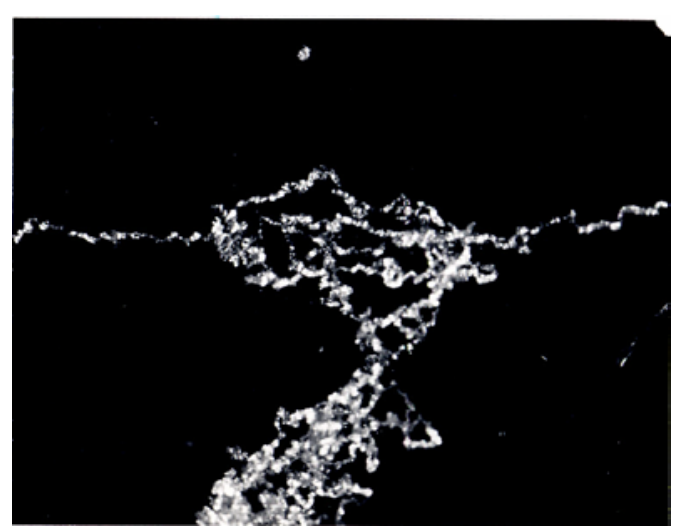

Fig. 3. Optical micrograph of chips of aluminum alloy, S3M.

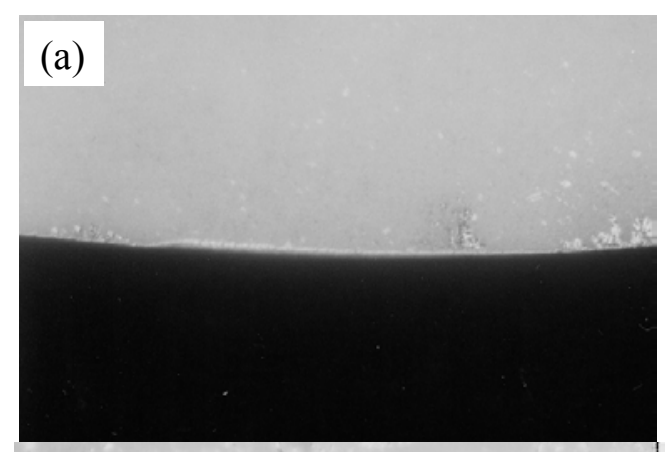

(b)

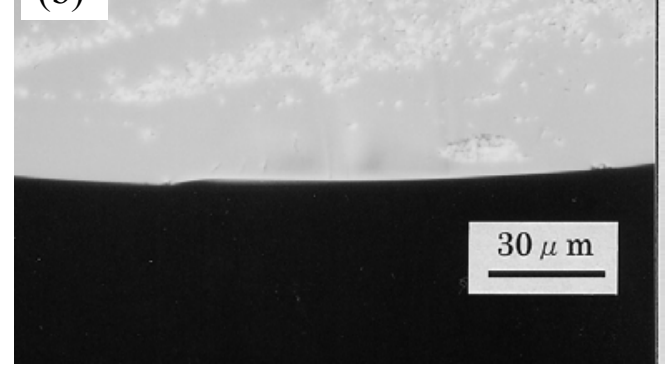

Fig. 4. Optical micrographs of the tool edge from rake direction after cutting S3M. Cutting length is $500 \mathrm{~km}$. (a) Fine-grained polycrystalline diamond, (b) Colorless single crystal.

(a) $\mathrm{Ra}=0.032 \mu \mathrm{m}$

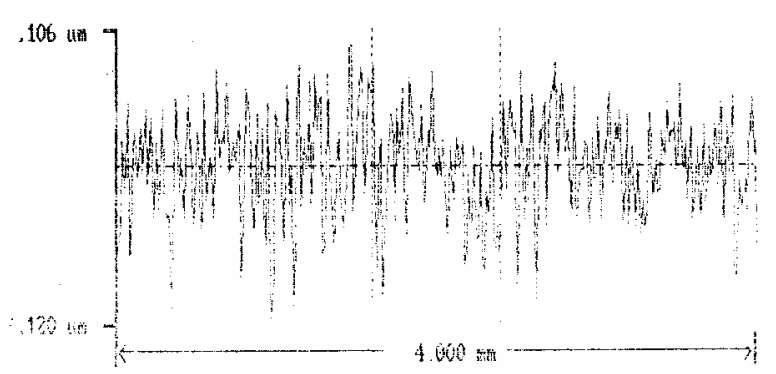

(b) $\mathrm{Ra}=0.033 \mu \mathrm{m}$

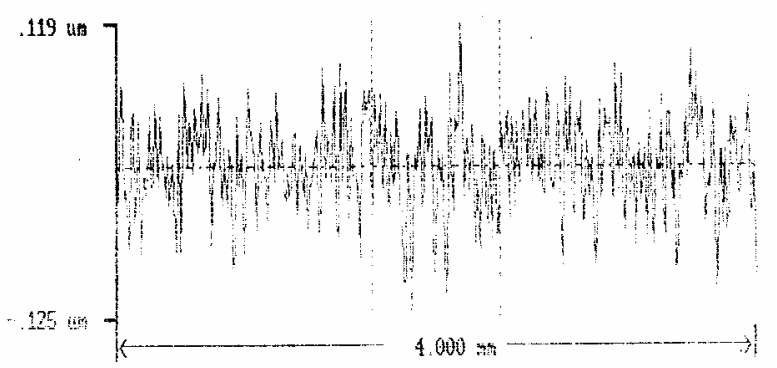

Fig. 5. Profiles of the finished surface of S3M after 500 km cutting. (a) Fine-grained polycrystalline diamond, (b) Colorless single crystal. 


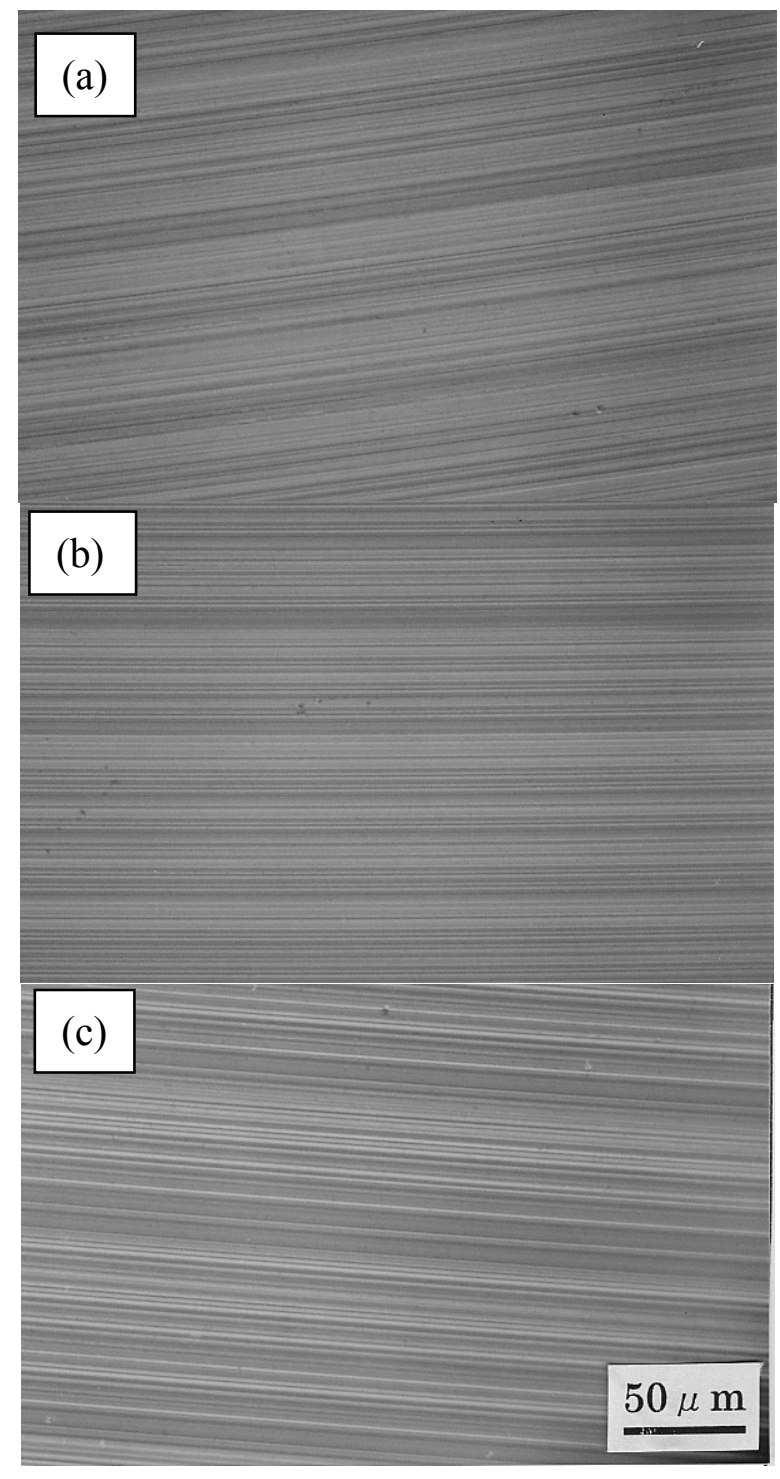

Fig. 6. Optical micrographs of the finished surface of S3M cut by fine-grained polycrystalline diamond tool. Cutting lengths (a) $10 \mathrm{~km}$, (b) $100 \mathrm{~km}$, (c) $300 \mathrm{~km}$.

被削材表面の光学顕微鏡観察を行った。多結晶体の 場合は加工長によらず，同じ樣な模樣が観察された (Fig. 6)。一方，単結晶は加工長により被削材の模樣に 変化が見られた(Fig. 7)。この結果は, 仕上げ面粗度の 測定結果とも対応している。

以上より $\mathrm{S} 3 \mathrm{M}$ の超精密加工において微粒ダイヤモ ンド多結晶体は単結晶と同等の仕上げ面粗度が得られ ることがわかった。

3. まとめ

精密部品に使用されている代表的な 2 種類のアルミ 合金 $\mathrm{ADC1} 12$ と $3 \mathrm{M}$ の超精密加工において, 微粒ダイ

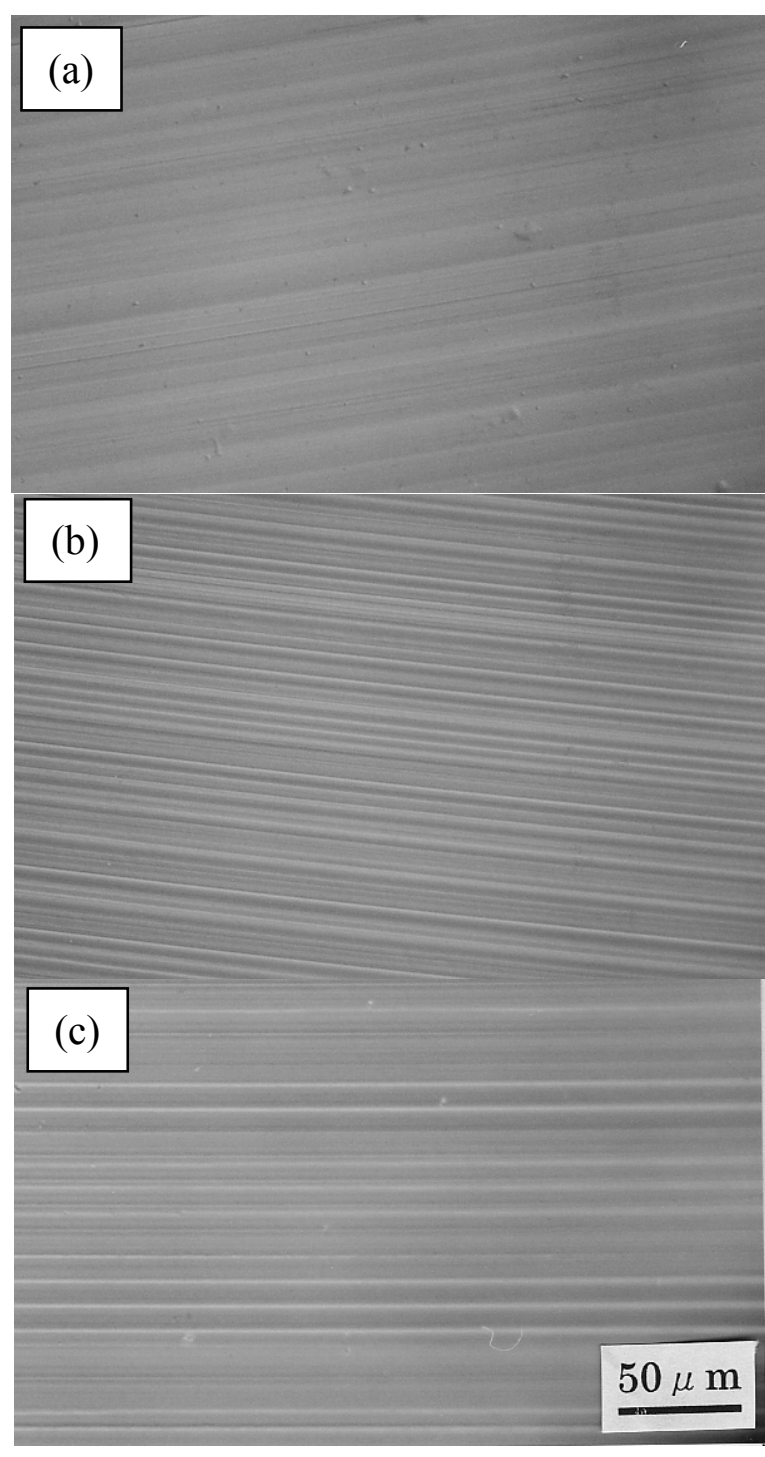

Fig. 7. Optical micrographs of the finished surface of S3M cut by single crystal tool. Cutting lengths (a) $10 \mathrm{~km}$, (b) $100 \mathrm{~km}$, (c) $300 \mathrm{~km}$.

ヤモンド多結晶体は単結晶ダイヤモンドと同等の仕上 げ面粗度と優れた面粗度の安定性を示すことが確認さ れた。面粗度のばらつきが小さいことは実際の大量加 工においては品質の安定性という観点から達成面粗度 と共に重要である。また，ADC12 の加工において多結 晶体は単結晶より優れた耐摩耗性を示すことが確認さ れた。

微粒ダイヤモンド多結晶体製超精密加工用工具には, 特性の安定化および多結晶体サイズの大面積化による コストダウンが期待される。また，多結晶体は単結晶 と異なり方位依存性がないので, 工具加工において研 磨方向の制約を受けず, 複雑形状刃先への対応も容易 である。切れ刃長に関しても単結晶より長いものに対 
応可能で, 工具刃先の自由度は大きい。例えば，多焦 点フレネルレンズの溝加工のような場合に V 型の単結 晶ダイヤモンド工具が使用されているが[13]，多結晶 体であれば $\mathrm{V}$ をたくさん集めた鋸刀状の工具を作製す ることも可能であると考えられる。樹脂製レンズ等の 精密金型の仕上げ加工は, 単結晶ダイヤモンド製エン ドミル等により行われている。精密金型加工で精度を 阻害する最も大きな要因は工具摩耗であるといわれて いる[14]。工具のわずかな摩耗で設計寸法からのズレ が生じるため，ほんのわずかな摩耗で工具は使用不可 となってしまう。微粒ダイヤモンド多結晶体は,ADC12 の端面切削において非常に優れた耐摩耗性を示してお り，旋削用としてだけでなく超精密加工用エンドミル としても高い可能性をもっていると考えられる。以上 のように微粒ダイヤモンド多結晶体工具は超精密加工 の可能性をさらに広げるものと期待される。

\section{参考文献}

[1] 工作機械技術研究会編: 工作機械 84 超精密加工, p.14 (大河出版, 1984).
[2] N. Ikawa, R.R. Donaldson, R. Komanduri, W. König, P.A. McKeown, T. Moriwaki, I.F. Stowers: Annals of the CIRP, 40, 587 (1991).

[3] 谷口紀男: ナノテクノロジの基礎と応用, p.72（工 業調査会, 1988).

[4] J.M. Oomen, J. Eisses: Precision Engineering, 14, 206 (1992).

[5] M. Akaishi, T. Ohsawa, S. Yamaoka: J.Am. Ceram. Soc., 74, 5 (1991).

[6] M.W. Cook: Industrial Diamond Review, 58, 15 (1998).

[7] 赤石實: 第 41 回高圧討論会講演要旨集, p.108 (2000).

[8] 大橋忠一, 山本和男, 赤石實: 第 42 回高圧討論会講 演要旨集, p.164 (2001).

[9] 大橋忠一，山本和男，赤石實: 第 42 回高圧討論会講 演要旨集, p.90(2001).

[10] 大橋忠一, 山本和男, 赤石實: 2002 年度精密工学 会春季大会講演論文集, p.547 (2002).

[11] T. Ohashi, K. Yamamoto, M. Akaishi: submitted.

[12] 日本軽金属技術資料.

[13] 竹内芳美: 精密工学会誌, 68, 167 (2002).

[14] 安斎正博, 2002 年度精密工学会春季大会講演論文 集, p.540 (2002).

[2002 年 11 月 20 日受理] 